\title{
Genital herpes as still significant dermatological, gynaecological and venereological problem
}

\author{
Katarzyna Plagens-Rotman ${ }^{1}$, Renata Przybylska², Katarzyna Gerke ${ }^{3}$ Zygmunt Adamski \\ Magdalena Czarnecka-Operacz ${ }^{3}$
}

${ }^{1}$ Hipolit Cegielski State University of Applied Sciences, Gniezno, Poland

${ }^{2}$ Department of Neurological Nursing, Poznan University of Medical Sciences, Poznan, Poland

${ }^{3}$ Department of Dermatology, Poznan University of Medical Sciences, Poznan, Poland

Adv Dermatol Allergol 2021; XXXVIII (2): 210-213

DOI: https://doi.org/10.5114/ada.2021.106198

\begin{abstract}
Genital herpes is one of the most commonly diagnosed sexually transmitted diseases and the most common factor in the formation of ulcers and erosions within the mucous membranes. It is characterized by a wide range of clinical symptoms from serous-filled blisters located on the erythematous and oedematous substrate to asymptomatic infection. Due to anatomical differences in the genital tract, there is a more than a 4-fold increase in the risk of a woman being infected by a partner than a man by a woman. In addition, the transmission of herpes simple virus from mother to foetus becomes a serious gynaecological and neonatal problem, especially in women of childbearing age. Despite epidemiological studies, the incidence of genital herpes has not been fully understood, probably due to lack of harmonization of disease reporting systems in many countries, and to difficulties in diagnosis and treatment.
\end{abstract}

Key words: herpes, reproductive organ, sexually transmitted diseases, treatment, prevention.

\section{Introduction}

Genital herpes is one of the most common sexually transmitted diseases caused by the herpes simple virus-2 (HSV-2) from the Herpesviridae family. The World Health Organization (WHO) estimates that around 20 million new HSV-2 infections are diagnosed each year worldwide, and around 86 million people experience genital herpes [1]. In Europe, the incidence of anti-HSV-2 antibodies in Bulgaria, England and Wales, and Poland is: $24 \%, 4 \%$ and $9.3 \%$, respectively [2]. A large percentage of infections is observed in Africa; among women it amounts up to even $30-80 \%$ and among men $10-50 \%$ [3]. In addition, a 3-fold increase in the risk of HIV infection is observed with the simultaneous occurrence of HSV-2, caused by skin damage in the genital area, buttocks and anal area [4], as well as an increased risk of developing other sexually transmitted diseases.

HSV-1 infection causes conjunctivitis, stomatitis or gingivitis as well as genital tract infections.
Risk factors include, first and foremost: low socioeconomic status, ethnicity, HSV infection in a sexual partner, female sex and other sexually transmitted infections [5, 6].

\section{Pathomechanism}

HSV-2 infection usually occurs between 18 and 30 years of age, regardless of sex, and the portal of entry is believed to be damages of the skin of genital, buttocks and anus area. The modified bacterial flora of the vagina may be an independent harbinger of seropositivity for the presence of HSV-2 virus. In case of the physiological microflora of the vagina, rods of Lactobacillus spp. genus, producing lactic acid and hydrogen peroxide, contribute to controlling the microenvironment, and thus inhibiting potential pathogenic microorganisms, while an insufficient amount of Lactobacillus is a factor increasing the risk of HSV-2 infection. Lactic acid bacteria also protect the vaginal microenvironment by producing protease inhibitors, helping to inhibit the development of Candida albicans hyphae. So-called bacteriocin compounds (acidophylline and lactocidin) also have bacte-

Address for correspondence: Katarzyna Plagens-Rotman PhD, Hipolit Cegielski State University of Applied Sciences, Gniezno, Poland, phone: 607-165-279, e-mail: plagens.rotman@gmail.com Received: 23.10.2019, accepted: 23.11.2019. 
riostatic and bactericidal activity [7]. In addition, bacterial vaginosis (BV) is characterized by excessive development of anaerobic bacteria: Gardnerella vaginalis (G. vaginalis), Mobiluncus spp., Bacteroides spp., Prevotella spp., Porphyromonas spp., Peptostreptococcus spp., Fusobacterium spp., Atopobium vaginae, which by producing metabolites inhibit the growth of Lactobacillus spp. [8].

When viruses enter the host epithelial cells, HSV-2 eplicates at the site of infection and in the regional lymph nodes leading to local inflammation. The multiplied particles penetrate into the sensory nerve endings, from where they are transported to nerve ganglia (S2-S4 cruciate ganglia), where they go into a state of latency. It should be strongly emphasized that during the asymptomatic period, the viruses may be present in cervical and vaginal secretions, urethral secretions or semen, creating a risk of infection of the partner.

\section{Clinical picture}

The clinical picture of genital herpes depends on many factors, such as the infection site, the type of virus or the patient's immune status. Before skin and mucosal changes occur, patients experience the so-called prodromal symptoms in the form of burning, itching and feeling of tension at the site of skin lesions which are formed later. Initially, small bubbles appear on the erythematous substrate, filled with serous contents on the labia and the vestibule of the vagina, later passing to the perineum, area of anus, affecting even the vagina and cervix turning into ulcers. Skin changes are often accompanied by general symptoms such as increased body temperature, feeling weak, muscle aches, and enlarged regional lymph nodes. In addition, dysuric symptoms, pelvic inflammatory disease (PID) are observed in women, while prostatitis herpetica in men [9].

Recurrent infection is not accompanied by systemic symptoms, and skin lesions most often appear at the site of primary infection.

\section{HSV infection diagnostics}

The diagnosis of genital herpes is mainly based on the medical history and clinical picture. About $20 \%$ of patients infected with HSV have typical symptoms in the form of painful vesicles filled with serous fluid containing virions in the genitourinary region that may occur briefly especially in the mucous membranes. However, most patients may have atypical changes in which symptoms can easily be confused with other genital dermatoses caused by other microorganisms (e.g. Treponema pallidum, Haemophilus ducreyi), non-infectious agents (e.g. Crohn's disease, Behçet's disease, hypersensitivity to drugs), and even suggest cancerous changes. For this reason, virological laboratory diagnostics is of the greatest importance in diagnosing HSV infection [10, 11].

\section{Direct HSV detection methods}

- Isolation of the virus from cell culture - the material for the study is a swab from the base of the lesion on the skin, fluid aspirated from the follicle as well as a swab from the mucous membranes of the genital organs (vulva, vaginal vestibule, vaginal top, cervical canal, cervical disc), urethra or perianal area. Alveolar fluid is recommended to be aspirated with a needle and syringe, and swabs from the lesion base with a cotton swab or with flocked nylon applicators [10, 12, 13].

The condition for obtaining reliable test results is the correct collection of material for the transport medium: 2-10\% foetal bovine serum (FBS), 1\% L-glutamine or Dulbecco's medium; time and conditions for storage and placement of the material in permissive cell culture.

Cytological diagnosis (Tzanck test) - the examined material is skin or mucosa eruption.

- Detection of viral DNA (polymerase chain reaction, PCR; realtime P(R) - the test material may involve cerebrospinal fluid, skin or mucosal lesions or unchanged mucosa. In addition, it is possible to detect mutations associated with drug resistance in material collected from patients [14] by determining the number of virus copies. Real-time PCR can be a method of monitoring infection and treating a patient with HSV.

- Detection of viral antigens (e.g. ELISA - enzyme-linked immunosorbent assay or EIA).

\section{Indirect HSV detection methods}

- Western Blot

- Enzyme immunoassay (EIA)

- POTC tests

Serological diagnostics are not used in patients who do not manifest symptoms of HSV infection [14-16], however, should be performed in specific clinical situations, such as: - in patients with a history of recurrent diseases of the genitourinary region, especially when direct diagnostic methods are negative [17],

- at the first episode of herpes to distinguish between primary and recurrent herpes [17],

- in sexual partners with diagnosed herpes and education in the field of sexually transmitted diseases prevention (use of condoms, total sexual abstinence),

- in pregnant women, especially if the partner had herpes regardless of its location [18],

- using the PCR method, a positive result of the presence of HSV DNA indicates an active infection threatening the foetus and the newborn [19].

In addition, DNA-HSV is often present in genital secretions, despite the absence of symptoms.

\section{Treatment}

In the event of clinical symptoms of genital herpes, treatment should be introduced as soon as possible to reduce the extent of skin lesions, and thus to reduce the duration of infection with the use of [20]: 
- for primary herpes, for 5-10 days one of the following medicines is recommended orally:

- Acyclovir 400 mg three times a day,

- Acyclovir 200 mg five times a day,

- Famciclovir 250 mg three times a day,

- Valaciclovir 500 mg twice a day;

- for recurrent herpes for a period of 5 days, one drug listed below orally:

- Acyclovir 400 mg three times a day or,

- Acyclovir 200 mg five times a day or,

- Valaciclovir 500 mg twice a day or,

- Famciclovir 125 mg twice a day;

- for HIV positive patients, the use of:

- Acyclovir $400 \mathrm{mg}$ five times a day for a period of 7 to 10 days,

- Valaciclovir 500 - 1000 mg twice a day for a period of 10 days,

- Famciclovir 250 - 500 mg three times a day for a period of 10 days.

\section{HSV infection in a pregnant woman and a newborn as a special obstetric and neonatal situation}

The risk of infection with genital herpes virus among pregnant women is high. It is estimated that in European countries positive results in pregnant women in Italy, Rome or among pregnant women living in northern Italy are lower than in the United States $7.6 \%, 8.4$ and $22 \%$ of pregnant women, respectively [21, 22].

In addition, in Italy, approximately $3 \%$ of pregnant women become infected during pregnancy, which results in miscarriages, intrauterine growth retardation (IUGR), preterm births or neonatal herpes infection [23]. In the third trimester of pregnancy, the risk of passing on the infection to a newborn baby is 30-50\%, whereas if the infection occurred earlier, the risk is about 1\%. In nearly $85 \%$ of cases, the transmission of HSV from mother to foetus occurs in the intra-natal period, and the risk of perinatal transmission of HIV to the newborn increases in women if there are clinical signs of urogenital herpes [24].

In the newborn, HSV infection manifests itself in the cutaneous and mucosal form, affecting mucous membranes and the eye (conjunctivitis, iritis and keratitis), generalized form including respiratory tract infection, liver and adrenal damage and intravascular coagulation syndrome, and as central nervous system infections resulting in disturbances of consciousness, psychomotor agitation, convulsive seizures, microphthalmia and hydrocephalus [25].

\section{Treatment of pregnant woman with HSV}

Medicines used in case of primary infections [26, 27]: - Acyclovir administered orally at a dose of $200 \mathrm{mg}$ five times a day for 7 to 10 days (as the best documented drug for pregnant women),
- Valaciclovir administered orally at a dose of $500 \mathrm{mg}$ twice a day or,

- Famciclovir at a dose of 250 mg twice a day.

Topical treatment is not recommended due to its low effectiveness. In severe cases, treatment should be given at intensive care units with intravenous Acyclovir infusions at a dose of $5 \mathrm{mg} / \mathrm{kg}$ body weight every $8 \mathrm{~h}$ for a period of 5-7 days. In recurrent infections, Acyclovir 400 mg 3 times daily for 5 days. In pregnant women with a history of genital HSV infections, Acyclovir 400 mg 2-3 times daily should be implemented from 34-36 week until the end of pregnancy. Introduction of pharmacological prophylaxis in women with frequent recurrences of herpes labialis should be examined to reduce the risk of transmission of the virus to the newborn during the puerperium. Damage to the nipple or appearance of lesions within the mammary gland is an indication to stop breastfeeding [28, 29]. HSV infection in the urogenital area in the perinatal period is an indication for ending pregnancy by caesarean section. It is not recommended to place electrodes on the foetal scalp during delivery. In HIV-positive women with a medical history of genital herpes, $400 \mathrm{mg}$ Acyclovir is recommended three times a day from 32 weeks of pregnancy, especially in women planning to have a vaginal pregnancy.

\section{Handling a newborn [30]}

During the first 24-48 h, a newborn conjunctival, oropharyngeal and rectal swab should be taken. In the presence of symptoms manifesting herpes, culture of urine, blood and swabs from alveoli, conjunctiva, oropharynx and anus/stool for virus should be performed. Ophthalmological and neurological consultation. In newborns infected with HSV intravenous Acyclovir 60 mg/kg daily; if HSV infection is limited to the skin, eyes and mouth, treatment for 14 days is recommended, and in case of the disseminated form or central nervous system involvement, continuation of treatment should be extended to 21 days. Monitoring of newborns for 4-6 weeks.

\section{Prevention}

- Detailed medical history in women with suspected genital herpes infection.

- Observation for occurrence of vesicular lesions and erosions on the erythematous basis within the genitourinary area.

- Palpation of adjacent lymph nodes.

- Observation for repetitive dysuric ailments and presence of skin lesions with simultaneous observation of systemic symptoms, i.e. increased body temperature, general malaise or muscle pain.

- Patient's education:

Oral, vaginal or anal sex with a person infected with HSV can be the portal of entry for genital herpes infection, 
The occurrence of a full-blown infection can be a reason for spreading the infection to a partner and other body surfaces,

The most effective prevention of genital herpes infection in the event of clinical symptoms is sexual abstinence, especially in women in the third trimester of pregnancy,

Condoms reduce the risk but do not completely prevent infection itself.

\section{Summary}

Despite epidemiological studies, the incidence of genital herpes has not been fully understood, probably due to the lack of harmonization of disease reporting systems in many countries, and to difficulties in diagnosis and treatment. However, it is crucial to popularize counselling in the field of ways of HSV spreading, transmission and prevention, especially among pregnant women.

\section{Conflict of interest}

The authors declare no conflict of interest.

\section{References}

1. Workowski KA, Levine WC, Wasserheit JN; Centers for Disease Control and Prevention, Atlanta, Georgia: U.S. Centers for Disease Control and Prevention guidelines for the treatment of sexually transmitted diseases: an opopportunity to unify clinical and public health practice. Ann Intern Med 2002; 137: 255-62.

2. Smith JS, Rosinska M, Trzcinska A, et al. Type specific seroprevelence of HSV-1 and HSV-2 in four geographical regions of Poland. Sex Transm Infect 2006; 82: 159-63.

3. Weiss H. Epidemiology of herpes simplex virus type 2 infection in the developing world. Herpes 2004; 11: 24A-35A.

4. Freeman EE, Weiss HA, Glynn JR, et al. Herpes simplex virus 2 infection increases HIV acquisition in men and women: systematic review and meta-analysis of longitudinal studies. AIDS 2006; 20: 73-83.

5. Gaydos C, Hardick J. Point of care diagnostics for sexually transmitted infections: perspectives and advances. Expert Rev Anti Infect Ther 2014; 12: 657-72.

6. Looker K, Garnet G. A systematic review of the epidemiology and interaction of herpes simplex virus types 1 and 2 . Sex Transm Infect 2005; 81: 103-7.

7. Strus M, Brzychczy-Wloch M, Kucharska A, et al. Działanie in vitro bakterii z rodzaju Lactobacillus izolowanych z pochwy na grzyby wywołujące kandydozę sromu i pochwy. Med Dośw Mikrobiol 2005; 55: 7-17

8. Cherpes TL, Meyn LA, Krohn MA, Hillier SL. Risk factors for infection with herpes simplex virus type 2: role of smoking, douching, uncircumcised males and vaginal flora. Sex Transm Dis 2003; 30: 405-10.

9. Straface G, Selmin A, Zanardo V, et al. Herpes simplex virus infection in pregnancy. Inf Dis Obstet Gynaecol 2012; 2012: 385697.

10. Domeika M, Bashmakova M, Savicheva A, et al. Eastern European Network for Sexual and Reproductive Health (EE SRH Network). Guidelines for the laboratory diagnosis of genital herpes in eastern European countries. Euro Surveill 2010; 15: pii: 19703.

11. Tomkins A, White C, Higgins SP. Primary herpes simplex virus infection mimicking cervical cancer. BMJ Case Rep 2015; 2015: bcr2015210194.

12. Anderson NW, Buchan BW, Ledeboer NA. Light microscopy, culture, molecular, and serologic methods for detection of herpes simplex virus. J Clin Microbiol 2014; 52: 2-8.

13. Biškup UG, Uršič T, Petrovec M. Laboratory diagnosis and epidemiology of herpes simplex 1 and 2 genital infections. Acta Dermatovenerol Alp Pannonica Adriat 2015; 24: 31-5.

14. Gnann J, Whitley RJ. Clinical practice. Genital herpes. N Engl J Med 2016; 375: 666-74.

15. Corey L, Wald A, Patel R, et al. Once-daily valacyclovir to reduce the risk of transmission of genital herpes. N Engl J Med 2004; 350: 11-20.

16. Ramaswamy M, McDonald C, Sabin C, et al. The epidemiology of genital infection with herpes simplex virus types 1 and 2 in genitourinary medicine attendees in inner London. Sex Transm Infect 2005; 81: 306-8.

17. Casper C, Wald A. Condom use and the prevention of genital herpes acquisition. Herpes 2002; 9: 10-4.

18. Tita AT, Grobman WA, Rouse DJ. Antenatal herpes serologic screening: an appraisal of the evidence. Obstet Gynecol 2006; 108: 1247-53.

19. Berardi A, Gallo C, Lugli L, et al. Foetal pneumonia following maternal HSV-1 viraemia in late pregnancy. J Matern Fetal Neonatal Med 2015; 28: 1694-6.

20. Patel R, Kennedy OJ, Clarke E, et al. 2017 European guidelines for the management of genital herpes. Int J STD AIDS 2017; 28: 1366-79.

21. Suligoi B, Cusan M, Santopadre P, et al. HSV-2 specific seroprevalence among various populations in Rome, Italy. The Italian Herpes Management Forum. Sex Transm Infect 2000; 76: 213-4

22. Baker DA. Consequences of herpes simplex virus in pregnancy and their prevention. Curr Opin Infect Dis 2007; 20: 73-6.

23. Brown ZA, Selke $S$, Zeh J, et al. The acquisition of herpes simplex during pregnancy. N Engl J Med 1997; 337: 509-15.

24. Enright AM, Prober CG. Neonatal herpes infection: diagnosis, treatment and prevention. Semin Neonatol 2002; 7: 283-91.

25. Guerra B, Puccetti C, Cervi F. The genital herpes problem in pregnancy. G Ital Dermatol Venereol 2012; 147: 455-66.

26. Rekomendacje Polskiego Towarzystwa Ginekologicznego, dotyczące zakażeń wirusem opryszczki zwykłej u kobiet ciężarnych. Ginekol Pol 2015; 86: 715-7.

27. James SH, Kimberlin DW. Neonatal herpes simplex virus infection: epidemiology and treatment. Clin Perinatol 2015; 42: 47-59.

28. Jaiyeoba O, Amaya MI, Soper DE, et al. Preventing neonatal transmission of herpes simplex virus. Clin Obstet Gynecol 2012; 55: 510-20.

29. Lanari M, Sogno Valin P, Natale F, et al. Human milk, a concrete risk for infection? J Matern Fetal Neonatal Med 2012; 25: $75-7$.

30. Kimberlin DW, Lin CY, Jacobs RF, et al. Safety and efficacy of high-dose intravenous acyclovir in the management of neonatal herpes simplex virus infections. Pediatrics 2001; 108: $230-8$. 